\title{
Factors Associated with Foliar Disease of Staked Fresh Market Tomatoes Grown Under Differing Bed Strategies
}

\author{
Douglas J. Mills, C. Benjamin Coffman, and John R. Teasdale, Sustainable Agricultural Systems Laboratory, \\ Plant Sciences Institute, Henry A. Wallace-Beltsville Agricultural Research Center, Beltsville, MD 20705; Kath- \\ ryne L. Everts, Department of Natural Resource Science and Landscape Architecture, University of Maryland, \\ Lower Eastern Shore Research and Education Center, Salisbury 21801, and Department of Plant and Soil Science, \\ University of Delaware, Research and Education Center, Georgetown 19947; and James D. Anderson, Associate \\ Director, Plant Sciences Institute, Henry A. Wallace-Beltsville Agricultural Research Center, Beltsville, MD 20705
}

\begin{abstract}
Mills, D. J., Coffman, C. B., Teasdale, J. R., Everts, K. L., and Anderson, J. D. 2002. Factors associated with foliar disease of staked fresh market tomatoes grown under differing bed strategies. Plant Dis. 86:356-361.

The use of mulch or compost to reduce foliar disease in fresh market tomato could reduce fungicide use. Between 1997 and 1999, foliar disease was monitored in tomatoes grown in beds with bare soil, black polyethylene, composted dairy manure, or hairy vetch. Early blight was reduced in plots with vetch compared with bare soil or compost in all years and compared with polyethylene cover in 1 year. Early blight was reduced in plots with polyethylene versus compost and bare soil in 1 and 2 years, respectively. Septoria leaf spot was reduced in plots with vetch versus other bed strategies in 1998 and bare soil or compost in 1999. This disease was reduced in plots with polyethylene versus bare soil or compost in 1998 and 1999. Soil coverage of tomato leaflets and soil particle dispersal were reduced in plots with polyethylene or vetch versus bare soil or compost in both years that these variables were assessed. Sensor wetness duration was reduced in plots with polyethylene or vetch versus bare soil or compost in one of two years. These findings suggest that foliar disease reduction in mulch was associated with reduced splash dispersal and, in one year, reduced leaf wetness.
\end{abstract}

Additional keywords: high input, low input, sustainable agriculture

The profitable production of fresh market tomatoes in the mid-Atlantic region of the United States depends on effective foliar disease management. Calendar-based application of fungicide typically is used to manage foliar disease incited by fungi (20), although integrated pest management (IPM) programs are becoming increasingly common in tomato production in the southeastern United States (3). The calendar-based application of fungicide usually consists of spraying at 7- to 10-day intervals beginning soon after transplant and continuing through harvest (20). Although this is an effective disease management tactic, calendar-based spraying can result in the over-application of fungicide when weather conditions discourage foliar disease development. Due to rising fungicide costs, increasing restrictions on fungicide use, resistance in fungal populations, and

Corresponding author: C. Benjamin Coffman

E-mail: ccoffman@ba.ars.usda.gov

Accepted for publication 23 October 2001.

Publication no. D-2002-0212-01R

This article is in the public domain and not copyrightable. It may be freely reprinted with customary crediting of the source. The American Phytopathological Society, 2002. environmental concerns associated with pesticide use in general, prudent fungicide use is becoming increasingly desirable.

The design of production systems that intrinsically discourage foliar disease development offers a potential means to reduce current levels of fungicide use. Cultural methods that suppress foliar disease in tomato could serve as the foundation of such production systems. In some pathosystems, compost amendment and cover cropping are cultural methods that can reduce pathogen populations or disease severity. For example, plant stand in pepper affected by Phytophthora capsici Leonian was higher in compost-amended soil compared with polyethylene mulch (17). The use of a wheat cover crop was shown to reduce the incidence of Phytophthora blight in peppers compared with bare soil or polyethylene mulch (16). This reduction was due to reduced dispersal of propagules of $P$. capsici, the causal agent of Phytophthora blight (16). Similarly, a sudangrass (Sorghum bicolor var. sudanensis cv. Trudan 8) cover crop was shown to reduce the splash dispersal of conidia of Colletotrichum acutatum Simmonds, the causal agent of anthracnose of strawberry (12). In addition, the incidence of leather rot disease of strawberry, caused by Phytophthora cactorum Lebert \& Cohn, was reduced with straw soil cover versus no soil cover, sand, or polyethylene mulch, presumably due to the reduced splash dispersal of sporangia (10). In processing tomato, the level of foliar necrosis, presumably associated with foliar disease, was reduced when plants were grown in an organic mulch formed by residue of the winter annual legume, hairy vetch, compared with black polyethylene mulch (1). Although few data exist regarding foliar pathogen behavior in hairy vetch mulch, soilborne fungal populations of Rhizoctonia and Pythium genera were shown to increase in hairy vetch (18), while Thielaviopsis basicola Berk. \& Broome was shown to decline $(5,18)$.

Early blight, caused by Alternaria solani Sorauer, and Septoria leaf spot, caused by Septoria lycopersici Speg., are common foliar diseases in the mid-Atlantic region. Thus, the suppression of these diseases generally is regarded as an important component of disease management programs for tomato in this region. Investigations of Septoria leaf spot and early blight have provided insight into how production systems could naturally limit the severity of these diseases. Rain has been shown to be necessary for the effective dispersal of conidia of $S$. lycopersici $(13,14)$.

Lesion formation on older tomato leaflets incubated with $S$. lycopersici was greater under extended periods of leaf wetness or relative humidity or when temperatures were between 20 and $25^{\circ} \mathrm{C}$ (7). The germination of $A$. solani conidia occurs at temperatures as high as $34^{\circ} \mathrm{C}$ or under relative humidity as low as $90 \%$ (19). As few as $3 \mathrm{~h}$ of continuous leaf wetness between 21 and $25^{\circ} \mathrm{C}$ is sufficient for early blight lesion formation (11). Host nutrition also can influence early blight development as observed when infection of tomato by $A$. solani decreased under high $\mathrm{N}$, high $\mathrm{P}$, or low $\mathrm{K}$ (23). These findings collectively indicate that production systems that discourage splash dispersal, microenvironmental conditions or host nutrition conducive to disease development may intrinsically limit the severity of these foliar diseases.

The objectives of this study were (i) to compare foliar disease epidemics in staked fresh market tomatoes grown in bare soil, 
bare soil covered with black polyethylene, bare soil amended with composted dairy manure, or hairy vetch mulch and (ii) to identify factors associated with variable disease severity among these bed strategies.

\section{MATERIALS AND METHODS}

This analysis of factors associated with differential disease development is one component of a larger field study designed to investigate foliar disease in tomato under combinations of bed strategy, fungicide spray schedule, and cultivar. In the larger study, the fungicide spray schedules included no sprays, weekly sprays, and sprays based on disease-forecasting model predictions. Treatments were randomized in a split split-plot design. Bed strategy was the main plot. There were six beds in each $43 \times 10 \mathrm{~m}$ main plot. Two subplots were formed in each main plot by planting three adjacent beds with one cultivar and the remaining three adjacent beds with another cultivar. Spray schedule was the sub-subplot. The sub-subplots were oriented perpendicularly to the long axis of the beds to create three sub-subplots within each subplot. Each sub-subplot was $14.3 \times$ $5 \mathrm{~m}$. There were three replicates per treatment in 1997 and four replicates per treatment in 1998 and 1999.

Site preparation. The experiment was conducted at the South Farm of the Henry A. Wallace-Beltsville Agricultural Research Center in Beltsville, MD, from 1997 to 1999 . Two adjacent fields were cropped to a 2-year rotation between fresh market tomato and sweet corn, so the same field was used in 1997 and 1999. The four bed strategies were bare soil, bare soil amended with composted dairy manure, soil covered with black polyethylene mulch, and hairy vetch mulch. The cover crop, hairy vetch (Vicia villosa Roth), is an annual legume that can serve as organic mulch $(1,2)$. Composted dairy manure was generated on site. Compost analysis revealed mean values of $35.9 \%$ for organic content, $8.7 \mathrm{pH}$, $3,278 \mathrm{~kg} / \mathrm{ha}$ for $\mathrm{Ca}, 0.87 \mathrm{~kg} / \mathrm{ha}$ for $\mathrm{Cu}, 492$ $\mathrm{kg} / \mathrm{ha}$ for $\mathrm{K}_{2} \mathrm{O}, 328 \mathrm{~kg} / \mathrm{ha}$ for $\mathrm{Mg}, 72 \mathrm{~kg} / \mathrm{ha}$ for $\mathrm{Mn}, 220 \mathrm{~kg} / \mathrm{ha}$ for $\mathrm{NO}_{3}, 820 \mathrm{~kg} / \mathrm{ha}$ for $\mathrm{P}_{2} \mathrm{O}_{5}, 100 \mathrm{~kg} / \mathrm{ha}$ for $\mathrm{SO}_{4}$, and $12.2 \mathrm{~kg} / \mathrm{ha}$ for $\mathrm{Zn}$.

In the mid-Atlantic region, the vetch system is predicated on cover crop establishment in the fall that precedes the tomato-growing season. Sowing the vetch seeds in early fall permits sufficient cover crop growth to protect the soil during the subsequent winter and spring seasons. Site preparation began in mid-September of 1996 with bed formation in hairy vetch plots to prepare for the 1997 tomato growing season. Beds were $15 \mathrm{~cm}$ in height and $0.9 \mathrm{~m}$ across with $1.5 \mathrm{~m}$ between bed centers for all bed strategies. After bed formation in hairy vetch plots, hairy vetch seeds inoculated with a commercial preparation of Rhizobium species were sown at a rate of $45 \mathrm{~kg} / \mathrm{ha}$ in these plots. This process of hairy vetch plot preparation was repeated in the fall of 1997 and 1998 to prepare for the 1998 and 1999 field seasons, respectively. In April of 1997, 1998, and 1999, composted dairy manure was incorporated into the compost plots at a rate of 15 metric tons/ha. This was followed by bed preparation in compost, bare soil, and black polyethylene plots in early May of 1997, 1998, and 1999. After this episode of bed preparation, black polyethylene mulch and drip irrigation lines were installed concurrently in black polyethylene plots. The irrigation lines were placed beneath the polyethylene. Following bed formation in all years, the preplant herbicide napropamide (Devrinol DF, $1.68 \mathrm{~kg}$ a.i./ha) was applied to the soil surface in bare soil, black polyethylene, and compost plots.

Bed preparation was completed in hairy vetch plots when the vetch was cut with a high-speed flail mower on 28 May 1997, 27 May 1998, and 19 May 1999. The mower was positioned $5 \mathrm{~cm}$ above the bed surface to kill the vetch and create a continuous layer of organic mulch in the vetch plots. On the following day in each year, seedlings were transplanted mechanically into the beds in all plots. A 1-liter solution of Peter's Plant Starter fertilizer (9N-45P$15 \mathrm{~K}$ at $0.28 \mathrm{~kg}$ per 100 liters of water) was applied with each transplant. The distance between each transplant was $0.38 \mathrm{~m}$. Prior to transplanting, tomato seedlings were treated with the insecticide imidacloprid (Admire 2 Flowable, $0.0952 \mathrm{~g}$ a.i. per seedling) to manage Colorado potato beetle (Leptinotarsa decemlineata Say). The Mountain Pride and Sunbeam cultivars were selected due to their commercial popularity. Mountain Pride is tolerant to early blight (9), although few differences in early blight severity between cultivars were observed. Immediately following transplant, drip irrigation lines were installed on the bed surface approximately 10 $\mathrm{cm}$ from the seedling base in bare soil, compost, and hairy vetch plots. The weekly drip irrigation rate was $3.8 \mathrm{~cm}$. Following transplant in each year, metribuzin (Lexone DF, $0.50 \mathrm{~kg}$ a.i./ha) was applied once in all plots in early June to manage weeds emerging after crop establishment. Manual weeding was performed during the growing season when necessary. The crop was physically supported using a traditional stake and string system that consisted of three stringing episodes per growing season. The timing of each stringing event was determined by the rate of crop growth. Spot stringing was performed to repair broken twine when necessary.

The fertilization program began in June of each year. This consisted of four episodes of urea application at 3-week intervals. Urea was dissolved in the irrigation water and introduced to the tomato crop through the irrigation system. Total urea application was $100 \mathrm{~kg} / \mathrm{ha}$ for hairy vetch plots and $200 \mathrm{~kg} / \mathrm{ha}$ for bare soil, black polyethylene, and compost plots. These rates were selected to duplicate previously determined $\mathrm{N}$ requirements for the bare soil, black polyethylene, and hairy vetch systems (2).

Disease assessment. Early blight and Septoria leaf spot epidemics developed from natural sources of inoculum, and the disease progress data reported here were collected exclusively in sub-subplots without fungicide. Separate disease assessments were made for early blight and Septoria leaf spot in 1998 and 1999. Disease was assessed weekly and consisted of visually estimating foliar symptoms on five plants in the interior row of each subsubplot. These five plants were chosen from among those plants harvested for the yield component of the larger study. Five leaflets from the lower, middle, and upper canopy levels of each plant were scored for the percentage of symptomatic area per leaflet. For each sub-subplot, the mean value of weekly disease severity per leaflet at each canopy level was used to compute the area under the disease progress curve (AUDPC) value for the lower, middle, and upper canopy level. The trapezoidal method was used to compute the AUDPC value (4).

Soil splash dispersal assays. Two assays were conducted to measure the raindriven dispersal of soil particles in each bed strategy. The first assay involved estimating the percentage of soil particle coverage of the upper and lower surfaces of the tomato leaflet due to rain-driven dispersal. This was accomplished through the visual estimation of soil coverage of both leaflet surfaces. Estimates were made on leaflets positioned $15 \mathrm{~cm}$ above the bed surface on plants in the interior row of each sub-subplot. Data for each cultivar and leaflet surface were combined to provide the estimate of total leaflet coverage. There were four replicates and eight samples taken per plot. The second assay involved estimating the height and magnitude of soil particle dispersal by rain in each bed strategy. This was accomplished by inserting a splash panel into the bed 20 $\mathrm{cm}$ from its edge to avoid direct contact with tomato plants. The panel was 15 (height) $\times 6$ (width) $\mathrm{cm}$ and contained a grid of $1 \mathrm{~cm}^{2}$ units. After rainfall, each 1 $\mathrm{cm}^{2}$ unit at each height level was scored for the presence of soil particles. The percentage of splash panel coverage reflects the percentage of $1 \mathrm{~cm}^{2}$ units on the panel that contained soil. Splash panels were cleaned after each assessment and cleaned again when the forecast predicted rain. To simplify presentation, the splash panel grid was grouped into five height levels that included 1 to 3,4 to 6,7 to 9,10 to 12 , and 13 to $15 \mathrm{~cm}$ above the bed surface. There were four replicates and two samples taken per plot.

Microenvironment measurement. Sensor wetness duration and air temperature 
during the sensor wetness period were measured in each bed strategy in 1998 and 1999. Due to physical and economic limitations, only two of the four replicates of the Sunbeam cultivar were monitored. Monitored plots received weekly fungicide applications since microenvironment analysis was part of the larger study. Sensors were cleaned frequently to remove pesticide residue and other debris. A $21 \mathrm{X}$ data logger (Campbell Scientific, Inc., Logan, UT) was used to record and store measurements from the thermistor temperature sensors (107 Air Temperature Probe, Campbell Scientific) and surface wetness sensors (Campbell Scientific). Measurements were recorded every minute, and the mean hourly value was recorded and stored in the data logger. Data were downloaded weekly.

Table 1. Variance analysis for the area under the disease progress curve (AUDPC) value for early blight (EB) and Septoria leaf spot (SLS) epidemics ${ }^{\mathrm{y}}$

\begin{tabular}{lcccccc}
\hline & \multicolumn{3}{c}{ AUDPC/EB } & & \multicolumn{2}{c}{ AUDPC/SLS } \\
\cline { 2 - 3 } \cline { 6 - 7 } & $\mathbf{1 9 9 7}$ & $\mathbf{1 9 9 8}$ & $\mathbf{1 9 9 9}$ & & $\mathbf{1 9 9 8}$ & $\mathbf{1 9 9 9}$ \\
\hline $\mathrm{BS}^{\mathrm{z}}$ & 0.0001 & 0.0001 & 0.0001 & & 0.0001 & 0.0001 \\
$\mathrm{C}$ & 0.5586 & 0.0006 & 0.5118 & & 0.4233 & 0.0436 \\
$\mathrm{~L}$ & 0.0001 & 0.0001 & 0.0001 & & 0.0001 & 0.0001 \\
$\mathrm{BS} \times \mathrm{C}$ & 0.9253 & 0.1253 & 0.2869 & & 0.5745 & 0.1868 \\
$\mathrm{BS} \times \mathrm{L}$ & 0.0356 & 0.0045 & 0.0001 & & 0.4690 & 0.0001 \\
$\mathrm{C} \times \mathrm{L}$ & 0.4565 & 0.0159 & 0.4779 & & 0.5506 & 0.6258 \\
$\mathrm{BS} \times \mathrm{C} \times \mathrm{L}$ & 0.9057 & 0.6931 & 0.9092 & & 0.9746 & 0.5369 \\
\hline
\end{tabular}

${ }^{y}$ Probabilities associated with the $F$ test for each treatment factor are presented. EB was detected in all 3 years and SLS in 1998 and 1999.

${ }^{\mathrm{z}} \mathrm{BS}$ is bed strategy (bare soil, black polyethylene, compost, hairy vetch), $\mathrm{C}$ is cultivar (Mountain Pride, Sunbeam), and L is canopy level (lower, middle, upper).

Table 2. Area under the disease progress curve (AUDPC) values for the lower, middle, and upper levels of the tomato canopy for the early blight (EB) and Septoria leaf spot (SLS) epidemics ${ }^{y}$

\begin{tabular}{lccl}
\hline & \multicolumn{3}{c}{ AUDPC at various canopy levels } \\
\cline { 2 - 4 } Bed strategy & Lower & Middle & Upper \\
\hline 1997/EB & & & \\
Bare soil & $978 \mathrm{a}^{\mathrm{z}}$ & $814 \mathrm{a}$ & $3 \mathrm{~d}$ \\
Compost & $1010 \mathrm{a}$ & $610 \mathrm{ab}$ & $3 \mathrm{~d}$ \\
Polyethylene & $844 \mathrm{a}$ & $610 \mathrm{ab}$ & $4 \mathrm{~d}$ \\
Hairy vetch & $478 \mathrm{bc}$ & $228 \mathrm{~cd}$ & $4 \mathrm{~d}$ \\
1998/EB & & & \\
Bare soil & $220 \mathrm{a}$ & $130 \mathrm{~b}$ & $0.1 \mathrm{~d}$ \\
Compost & $165 \mathrm{ab}$ & $58 \mathrm{~cd}$ & $0 \mathrm{~d}$ \\
Polyethylene & $95 \mathrm{bc}$ & $34 \mathrm{~cd}$ & $0.1 \mathrm{~d}$ \\
Hairy vetch & $34 \mathrm{~cd}$ & $9 \mathrm{~d}$ & $0.1 \mathrm{~d}$ \\
1999/EB & & & $40 \mathrm{f}$ \\
Bare soil & $977 \mathrm{a}$ & $409 \mathrm{~d}$ & $31 \mathrm{f}$ \\
Compost & $900 \mathrm{a}$ & $426 \mathrm{~d}$ & $18 \mathrm{f}$ \\
Polyethylene & $731 \mathrm{~b}$ & $292 \mathrm{e}$ & $16 \mathrm{f}$ \\
Hairy vetch & $562 \mathrm{c}$ & $287 \mathrm{e}$ & $1 \mathrm{c}$ \\
1998/SLS & & & $3 \mathrm{c}$ \\
Bare soil & $177 \mathrm{a}$ & $121 \mathrm{a}$ & $0 \mathrm{c}$ \\
Compost & $336 \mathrm{a}$ & $44 \mathrm{~b}$ & $0 \mathrm{c}$ \\
Polyethylene & $89 \mathrm{a}$ & $6 \mathrm{c}$ & \\
Hairy vetch & $8 \mathrm{c}$ & $32 \mathrm{c}$ & $0 \mathrm{e}$ \\
1999/SLS & & $62 \mathrm{~b}$ & $0 \mathrm{e}$ \\
Bare soil & $378 \mathrm{a}$ & $0 \mathrm{e}$ & $0 \mathrm{e}$ \\
Compost & $452 \mathrm{a}$ & $0 \mathrm{e}$ & \\
Polyethylene & $0 \mathrm{e}$ & & $\mathrm{e}$ \\
Hairy vetch & $0 \mathrm{e}$ & & \\
- & & & \\
\hline
\end{tabular}

y EB was detected in all years and SLS in 1998 and 1999.

${ }^{\mathrm{z}}$ Means for the same disease and year followed by the same letter are not significantly different at $P$ $\leq 0.05$ according to LSD. There were three replicates in 1997 and four replicates per treatment in 1998 and 1999. at $10 \mathrm{~cm}$ above the bed surface to monitor surface wetness at the initial site of early blight symptom appearance. The sensors subsequently were placed in the middle canopy at a height of $40 \mathrm{~cm}$ above the bed surface to monitor surface wetness prior to symptom appearance in the middle canopy. The sensors eventually were placed in the upper canopy at a height of $60 \mathrm{~cm}$ above the bed surface to monitor surface wetness prior to symptom appearance in the upper canopy.

Foliar element assessment. The element content of tomato foliage was determined by the Soils Testing Laboratory at the University of Maryland, College Park. Mature leaflets taken from plants in plots without fungicide were dried, pulverized, placed in a labeled vial, and submitted to the Soils Testing Laboratory. There were three replicates in 1997, and four in 1998 and 1999. In 1997, leaflets were collected from the middle canopy level of both cultivars on 1 September during peak fruit ripening. In 1998, leaflets were harvested from the middle canopy level of both cultivars during early fruit development on 9 July, the onset of fruit ripening on $10 \mathrm{Au}$ gust, and peak fruit ripening on 28 August. In 1999, leaflets were collected from the lower and middle canopy levels of the Sunbeam cultivar on 20 July prior to fruit ripening when symptoms were confined to the lower canopy. Later, on 19 August, leaflets were harvested from the middle and upper canopy levels during peak fruit ripening when symptoms appeared in the middle but not upper canopy.

The PROC MIXED procedure of SAS version 6.12 was used for data analysis. This linear model accounts for both fixed and random effects. To satisfy ANOVA requirements, the AUDPC values for the SLS epidemics in 1998 and 1999 were log transformed, then back-transformed after analysis for presentation.

\section{RESULTS}

Disease severity. Early blight was detected in all years while Septoria leaf spot was detected in 1998 and 1999. The significant (Table 1) bed strategy by canopy level interaction for early blight in 1997 and 1998 was due to less disease in the lower and middle canopy levels in tomatoes grown in hairy vetch compared with the other bed strategies (Table 2). In 1999, this interaction for early blight was due to less disease in the lower and middle canopy levels in tomatoes grown in hairy vetch or black polyethylene compared with plots with bare soil or compost. The significant interaction between bed strategy and canopy level for Septoria leaf spot in 1999 was due to the absence of disease in tomatoes grown in hairy vetch or black polyethylene mulch compared with bare soil or compost (Table 2). There was a significant $F$ value for bed strategy in 1998 for the AUDPC value for Septoria leaf spot 
due to less disease in tomato grown in hairy vetch mulch compared with the other bed strategies.

The $F$ value for the bed strategy by cultivar interaction was not significant (Table 1). There were two instances where the $F$ value for cultivar was significant. The AUDPC value for early blight was greater for Mountain Pride than for Sunbeam in 1998. In 1999, the AUDPC value for Septoria leaf spot was greater for Sunbeam than for Mountain Pride. The $F$ value for canopy level was significant for the AUDPC values of early blight and Septoria leaf spot in all instances. There was a pattern of higher AUDPC values in the lower and middle canopy levels and lower AUDPC values in the upper canopy level.

Soil splash dispersal. In all instances, soil particle deposition on tomato foliage due to rain-driven splash dispersal was significantly affected by bed strategy. Following rainfall in 1998 and 1999 at all sampling dates, leaflets of plants in plots with black polyethylene or hairy vetch mulch exhibited less soil coverage compared with plots with bare soil or compost (Table 3 ). The $F$ value for bed strategy was significant for the percentage of units on the splash panel grid containing soil particles at all six sampling dates in 1998 and at three of five sampling dates in 1999. Soil coverage of the splash panel grid was lower in plots with hairy vetch compared with bare soil or compost at all sampling dates and lower compared with black polyethylene at five of six sampling dates in 1998 (Table 4). Also in 1998, soil coverage of the splash panel grid was lower in plots with black polyethylene than in plots with bare soil or compost at four of six sampling dates. When significant differences among bed strategy occurred at three of the 1999 sampling dates, soil coverage of the splash panel grid was lower in plots with hairy vetch compared with black polyethylene or compost. Coverage was lower in plots with hairy vetch compared with bare soil at two of these three 1999 sampling dates.

Microenvironment. The $F$ value for bed strategy was significant for the daily value of sensor wetness duration in 1998. In 1998, sensor wetness duration was lower in plots with black polyethylene or hairy vetch compared with bare soil or compost (Table 5). The $F$ value for sensor wetness duration was not significant in 1999.

Air temperature during the sensor wetness period in 1998 was significantly affected by bed strategy. Temperature was significantly higher in plots with black polyethylene mulch than in plots with other bed strategies. However, air temperature difference ranged from 0.3 to $2.0^{\circ} \mathrm{C}$, which seems insufficient to have influenced disease development significantly. The $F$ value for air temperature was not significant in 1999.

Foliar element content. There were instances when the $F$ value for bed strategy or cultivar was significant for the foliar content of some elements. The $\mathrm{P}$ content of tomato foliage was significantly lower in plots with hairy vetch mulch compared with all other bed strategies in 1997 (Table 6). Foliar P content also was lower in plots with compost compared with black polyethylene. In 1999, the foliar content of $\mathrm{Ca}$ was lower in plots with compost compared with all other bed strategies. Significant cultivar differences included higher foliar content of $\mathrm{K}$ and $\mathrm{Mg}$ for Sunbeam in 1997 and in 1998. The results from this assay indicate the absence of a consistent association between foliar element content and disease severity among bed strategies.

\section{DISCUSSION}

In these studies, there was a pattern of foliar disease reduction in tomatoes grown in beds with mulch compared with beds with an exposed soil surface. In addition, the relative reduction of early blight and Septoria leaf spot in tomatoes grown in mulch was more consistently associated with hairy vetch than with black polyethylene mulch. Splash dispersal of soil by rain was the factor that was most frequently associated with disease differences between plots with or without mulch. In plots with an exposed soil surface, the observed increase in soil splash dispersal suggests that dispersal of initial inoculum from the soil to tomato foliage was greater in plots with bare soil or compost. There is a previous report of increased soil particle deposition on tomato foliage in plots with mulch versus without mulch, although differences in disease between plots with or without mulch were not observed (6).

With the exception of two sampling dates, there was a comparative reduction of soil splash dispersal with hairy vetch mulch. This relative reduction of splash dispersal may have been due to complete coverage of the soil surface by the cover crop residue. Although inoculum dispersal in hairy vetch mulch was not investigated, other cover crops have been shown to reduce inoculum dispersal $(10,12,16)$. In pathosystems where initial inoculum is intraplot and soilborne, the disruption of soil dispersal to crop foliage by cover crop residue would be a desirable disease management tool. There were some instances when the relative reduction of soil splash dispersal in hairy vetch mulch continued to persist after decomposition of the cover crop residue. This suggests the existence of a more cohesive soil surface in plots with hairy vetch mulch compared with the other bed strategies. An increase in soil surface

Table 3. Percentage of tomato leaflet surface area covered with soil particles following rainfall in 1998 and $1999 \mathrm{y}$

\begin{tabular}{|c|c|c|c|c|c|c|c|c|}
\hline \multirow[b]{2}{*}{ Bed strategy } & \multicolumn{4}{|c|}{1998} & \multicolumn{4}{|c|}{1999} \\
\hline & 16 June & 24 June & 7 July & 6 August & 22 June & 24 June & 30 June & 16 August \\
\hline Bare soil & $12.0 \mathrm{a}^{\mathrm{z}}$ & $8.0 \mathrm{a}$ & $2.2 \mathrm{~b}$ & $2.3 \mathrm{a}$ & $20.9 \mathrm{a}$ & $6.4 \mathrm{a}$ & $6.8 \mathrm{a}$ & $8.8 \mathrm{a}$ \\
\hline Compost & $10.7 \mathrm{a}$ & $7.2 \mathrm{a}$ & $6.4 \mathrm{a}$ & $2.3 \mathrm{a}$ & $15.0 \mathrm{a}$ & $4.0 \mathrm{~b}$ & $5.2 \mathrm{a}$ & $7.6 \mathrm{a}$ \\
\hline Polyethylene & $0.6 \mathrm{~b}$ & $0.3 \mathrm{~b}$ & $0.9 \mathrm{~b}$ & $0.7 \mathrm{~b}$ & $0.8 \mathrm{~b}$ & $0.1 \mathrm{c}$ & $0.9 \mathrm{~b}$ & $1.4 \mathrm{~b}$ \\
\hline Hairy vetch & $0.1 \mathrm{~b}$ & $0.2 \mathrm{~b}$ & $0.2 \mathrm{~b}$ & $0.1 \mathrm{~b}$ & $0.1 \mathrm{~b}$ & $0.1 \mathrm{c}$ & $0.3 \mathrm{~b}$ & $2.1 \mathrm{~b}$ \\
\hline
\end{tabular}

${ }^{y}$ Leaflets at a height of $15 \mathrm{~cm}$ above the bed surface were sampled.

${ }^{\mathrm{z}}$ Means in each column at each sampling date followed by the same letter are not significantly different at $P \leq 0.05$ according to LSD. There were four replicates per treatment and eight samples taken per plot. Means represent the combined data for both cultivars and both leaflet surfaces.

Table 4. Percentage of splash panel covered by soil particles following rainfall in 1998 and 1999

\begin{tabular}{|c|c|c|c|c|c|c|c|c|c|c|c|}
\hline \multirow[b]{2}{*}{ Bed strategy } & \multicolumn{6}{|c|}{1998} & \multicolumn{5}{|c|}{1999} \\
\hline & 2 June & 11 June & 16 June & 24 June & 9 July & 20 July & 14 June & 15 June & 23 June & 30 June & 16 August \\
\hline Bare soil & $90 \mathrm{a}^{\mathrm{z}}$ & $84 \mathrm{a}$ & $86 \mathrm{a}$ & $91 \mathrm{a}$ & $85 \mathrm{a}$ & $93 \mathrm{a}$ & $97 \mathrm{a}$ & $100 \mathrm{a}$ & $64 \mathrm{a}$ & $92 \mathrm{ab}$ & $94 \mathrm{a}$ \\
\hline Compost & $83 \mathrm{a}$ & $81 \mathrm{a}$ & $85 \mathrm{a}$ & $90 \mathrm{a}$ & $70 \mathrm{a}$ & $92 \mathrm{a}$ & $98 \mathrm{a}$ & $100 \mathrm{a}$ & $55 \mathrm{a}$ & $98 \mathrm{a}$ & $96 \mathrm{a}$ \\
\hline Polyethylene & $51 \mathrm{~b}$ & $30 \mathrm{~b}$ & $25 \mathrm{~b}$ & $34 \mathrm{~b}$ & $65 \mathrm{a}$ & $90 \mathrm{a}$ & $92 \mathrm{a}$ & $84 \mathrm{a}$ & $52 \mathrm{a}$ & $95 \mathrm{a}$ & $95 \mathrm{a}$ \\
\hline Hairy vetch & $10 \mathrm{c}$ & $8 \mathrm{c}$ & $8 \mathrm{c}$ & $37 \mathrm{~b}$ & $43 \mathrm{~b}$ & $30 \mathrm{~b}$ & $0.5 \mathrm{~b}$ & $48 \mathrm{~b}$ & $62 \mathrm{a}$ & $84 \mathrm{~b}$ & $90 \mathrm{a}$ \\
\hline
\end{tabular}

${ }^{\mathrm{z}}$ Means in each column at each sampling date followed by the same letter are not significantly different at $P \leq 0.05$ according to LSD. Splash panel grid was grouped into five height levels that included 1-3, 4-6, 7-9, 10-12, and 13-15 cm above the bed surface prior to analysis. There were four replicates per treatment and two samples taken per plot. 
stability may reduce the probability of injury to tomato foliage by windborne soil particles. This is relevant to disease management since pepper plants injured by airborne soil particles were observed to display greater incidence of bacterial disease (15).

There was a reduction in the AUDPC value for the early blight epidemic in tomatoes grown in hairy vetch mulch compared with the other bed strategies in 1997. This reduction of early blight was due to a delay in epidemic onset and to a reduction in the epidemic rate. This finding led to the development of an assay to assess the susceptibility of tomato tissue to A. solani in each bed strategy. Except for a single instance of an apparent reduction in tissue susceptibility associated with hairy vetch mulch in 1997, differences in susceptibility among bed strategies were not observed (data not shown). Another explanation for the 1997 result is that early blight reduction in to-

Table 5. Mean values of daily sensor wetness duration (hours) for the 1998 and 1999 growing seasons

\begin{tabular}{lll}
\hline Bed strategy & $\mathbf{1 9 9 8}$ & $\mathbf{1 9 9 9}$ \\
\hline Bare soil & $6.5 \mathrm{a}^{\mathrm{z}}$ & $7.95 \mathrm{~ns}$ \\
Compost & $6.1 \mathrm{a}$ & 8.32 \\
Polyethylene & $4.8 \mathrm{~b}$ & 8.60 \\
Hairy vetch & $4.5 \mathrm{~b}$ & 7.87 \\
\hline
\end{tabular}

${ }^{\mathrm{z}}$ Means in the same column and year followed by the same letter are not significantly different at $P \leq 0.05$ according to LSD. There were two replicates, and two samples were taken per plot in 1998. In 1999, there were two replicates, and four samples were taken per plot. Only the Sunbeam cultivar plots were instrumented.

Table 6. Percent dry foliar weight composed of N, P, K, Ca, and Mg for bed strategies and cultivars during peak fruit ripening

\begin{tabular}{llllll}
\hline & \multicolumn{5}{c}{ \% element content } \\
\cline { 2 - 6 } Level & \multicolumn{1}{c}{$\mathbf{N}$} & $\mathbf{P}$ & $\mathbf{K}$ & $\mathbf{C a}$ & $\mathbf{M g}$ \\
\hline 9/1/97 & & & & & \\
Bare soil & $4.57 \mathrm{~ns}$ & $0.37 \mathrm{a} \mathrm{b}^{\mathrm{y}}$ & $2.12 \mathrm{~ns}$ & $3.37 \mathrm{~ns}$ & $0.53 \mathrm{~ns}$ \\
Polyethylene & 4.50 & $0.41 \mathrm{a}$ & 2.22 & 2.99 & 0.46 \\
Compost & 4.22 & $0.35 \mathrm{~b}$ & 2.43 & 3.15 & 0.49 \\
Hairy vetch & 3.92 & $0.29 \mathrm{c}$ & 1.90 & 2.89 & 0.43 \\
Mountain Pride & $4.19 \mathrm{~ns}$ & $0.36 \mathrm{~ns}$ & $1.98 \mathrm{~b}$ & $3.04 \mathrm{~ns}$ & $0.45 \mathrm{~b}$ \\
Sunbeam & 4.42 & 0.36 & $2.35 \mathrm{a}$ & 3.17 & $0.50 \mathrm{a}$ \\
8/28/98 & & & & & \\
Bare soil & $3.54 \mathrm{~ns}$ & $0.25 \mathrm{~ns}$ & $1.45 \mathrm{~ns}$ & $5.24 \mathrm{~ns}$ & $0.68 \mathrm{~ns}$ \\
Polyethylene & 3.24 & 0.28 & 1.49 & 5.05 & 0.61 \\
Compost & 3.15 & 0.24 & 1.53 & 4.71 & 0.66 \\
Hairy vetch & 3.47 & 0.27 & 1.79 & 4.80 & 0.63 \\
Mountain Pride & $3.17 \mathrm{~ns}$ & $0.26 \mathrm{~ns}$ & $1.48 \mathrm{~b}$ & $4.77 \mathrm{~ns}$ & $0.60 \mathrm{~b}$ \\
Sunbeam & 3.52 & 0.26 & $1.65 \mathrm{a}$ & 5.13 & $0.68 \mathrm{a}$ \\
8/19/1999 & & & & & \\
Bare soil & $3.63 \mathrm{~ns}$ & $0.28 \mathrm{~ns}$ & $1.52 \mathrm{~ns}$ & $5.69 \mathrm{a}$ & $0.88 \mathrm{~ns}$ \\
Polyethylene & 3.54 & 0.28 & 1.39 & $5.87 \mathrm{a}$ & 0.80 \\
Compost & 3.60 & 0.25 & 2.06 & $5.12 \mathrm{~b}$ & 0.76 \\
Hairy vetch & 3.57 & 0.27 & 1.47 & $5.85 \mathrm{a}$ & 0.85 \\
\hline
\end{tabular}

${ }^{\mathrm{y}}$ Means in columns within a sampling date followed by the same letter are not significantly different at $P \leq 0.05$ according to LSD. There were three replicates in 1997 and four replicates per treatment in 1999. Samples for analysis were drawn from a mixture of dried pulverized leaflets collected from plots without fungicide.

${ }^{z}$ Only the Sunbeam cultivar was evaluated in 1999. mato grown in hairy vetch mulch related to a variable rate of crop development in 1997. Investigation has shown that soil temperature is higher under black polyethylene compared with hairy vetch mulch (21), which suggests that different rates of crop development can occur between these two mulches. In addition, tomatoes grown allocate more resources to fruit production early in the season, whereas tomatoes grown in hairy vetch mulch allocate more resources to vegetative growth early in the season (22). It is possible that early blight reduction in plots with hairy vetch mulch in 1997 related to differences in crop physiological maturity or resource allocation patterns.

The observed variation in sensor wetness duration in 1998 may have related to differences in disease development among bed strategies. There was an association between greater surface wetness duration and greater disease severity in tomato grown in plots with bare soil or compost compared with mulched plots. The increase in sensor wetness duration in plots with bare soil or compost was observed before and during the early blight epidemic. Although the sensors provided only an approximation of leaf wetness duration, these data suggest that increased leaflet wetness duration contributed to greater disease severity in plots with bare soil or compost in 1998. Compared with bare soil or compost, the volume of the canopy, which was computed as the product of canopy height and width, was consistently greater in plots with black polyethylene or hairy vetch mulch (data not shown). This suggests that variable canopy volume related to differin black polyethylene mulch were shown to ences in sensor wetness duration between plots with or without mulch.

The mulch-based bed strategies offered some measure of foliar disease suppression compared with the bed strategies consisting of completely exposed soil surfaces. The relative reduction of soil splash dispersal in mulched beds was associated with less disease in the years this variable was measured. There was also an association between lower disease in mulched plots and reduced sensor wetness duration in 1998. This reduction of sensor wetness duration in mulched plots may have been due to increased volume of the tomato canopy. These observations suggest that soil splash dispersal was the factor most consistently associated with foliar disease suppression by mulches and that leaf wetness may be a factor under selected environmental conditions.

\section{LITERATURE CITED}

1. Abdul-Baki, A. A., Stommel, J. R., Watada, A E., Teasdale, J. R., and Morse, R. D. 1996. Hairy vetch mulch favorably impacts yield of processing tomatoes. HortScience 31:338340.

2. Abdul-Baki, A. A., Teasdale, J. R., and Korcak, R. F. 1997. Nitrogen requirements of fresh-market tomatoes on hairy vetch and black polyethylene mulch. HortScience 32:217-221.

3. Bauske, E. M., Zehnder, G. M., Sikora, E. J., and Kemble, J. 1998. Southeastern tomato growers adopt integrated pest management. Horttechnology 8:40-44.

4. Campbell, C. L., and Madden, L. V. 1990. Introduction to Plant Disease Epidemiology. John Wiley \& Sons, New York.

5. Candole, B. L., and Rothrock, C. S. 1997. Characterization of the suppressiveness of hairy vetch-amended soils to Thielaviopsis basicola. Phytopathology 87:197-202.

6. Creamer, N. G., Bennett, M. A., Stinner, B. R., and Carding, J. 1996. A comparison of four processing tomato production systems differing in cover crop and chemical inputs. J. Am. Soc. Hortic. Sci. 121:559-568.

7. Elmer, W. H., and Ferrandino, F. J. 1995. Influence of spore density, leaf age, temperature, and dew periods on Septoria leaf spot of tomato. Plant Dis. 79:287-290.

8. Gillespie, T. J., and Kidd, G. E. 1978. Sensing duration of leaf moisture retention using electrical impedance grids. Can. J. Plant Sci. 58:179-187.

9. MacNab, A. A., and Gardner, R. G. 1993. Early blight defoliation on tomatoes associated with cultivar and fungicide treatments, 1992. Biol. Cult. Tests 8:54.

10. Madden, L. V., and Ellis, M. A. 1990. Effect of ground cover on splash dispersal of Phytophthora cactorum from strawberry fruits. J. Phytopathol. 129:170-174.

11. Madden, L. V., Pennypacker, S. P., and MacNab, A. A. 1978. FAST, a forecast system for Alternaria solani on tomato. Phytopathology 68:1354-1358.

12. Ntahimpera, N., Ellis, M. A., Wilson, L. L., and Madden, L. V. 1998. Effects of a cover crop on splash dispersal of Colletotrichum acutatum conidia. Phytopathology 88:536543.

13. Parker, S. K., Gleason, M. L., and Nutter, F. W., Jr. 1995. Influence of rain events on spatial distribution of Septoria leaf spot of tomato. Plant Dis. 79:148-152.

14. Parker, S. K., Nutter, F. W., Jr., and Gleason, 
M. L. 1997. Directional spread of Septoria leaf spot in tomato rows. Plant Dis. 81:272-276.

15. Pohronezny, K., Hewitt, M., Infante, J., and Datnoff, L. 1992. Wind and wind-generated sand injury as factors in infection of pepper by Xanthomonas campestris pv. vesicatoria. Plant Dis. 76:1036-1039.

16. Ristaino, J. B., Parra, G., and Campbell, C. L. 1997. Suppression of Phytophthora blight in bell pepper by a no-till wheat cover crop. Phytopathology 87:242-249.

17. Roe, N. E., Stoffella, P. J., and Bryan, H. H. 1994. Growth and yields of bell pepper and winter squash grown with organic and living mulches. J. Am. Soc. Hortic. Sci. 119:11931199.

18. Rothrock, C. S., Kirkpatrick, T. L., Frans, R. E., and Scott, H. D. 1995. The influence of winter legume cover crops on soilborne plant pathogens and cotton seedling diseases. Plant Dis. 79:167-171.

19. Sherf, A. F., and MacNab, A. A. 1986. Vegetable Diseases and Their Control. 2nd ed. John Wiley \& Sons, New York.

20. Sikora, E. J., Bauske, E. M., Zehnder, G. W., and Hollingsworth, M. H. 1994. Evaluation of low-input fungicide spray programs for control of early blight on tomatoes. Ala. Agric.
Exp. Stn. Highlights Agric. Res. 41:15

21. Teasdale, J. R., and Abdul-Baki, A. A. 1995 Soil temperature and tomato growth associated with black polyethylene and hairy vetch mulches. J. Am. Soc. Hortic. Sci. 120:848853.

22. Teasdale, J. R., and Abdul-Baki, A. A. 1997. Growth analysis of tomatoes in black polyethylene and hairy vetch production systems. HortScience 32:659-663.

23. Thomas, H. R. 1948. Effect of nitrogen, phosphorus and potassium on susceptibility of tomatoes to Alternaria solani. J. Agric. Res. 76:289-306. 